\title{
A FŐISKOLAI HALLGATÓK ÉLETMÓDJA ÉS SPORTTAL KAPCSOLATOS SZOKÁSAIK
}

\section{Szerzők:}

Vida Júlia

Gál Ferenc Főiskola (Magyarország)

Dr. Fest Sarolta (PhD.)

Gál Ferenc Főiskola (Magyarország)

Levelező szerző:

fest.sarolta@pk.gff-szarvas.hu

\section{Lektorok:}

Szabóné Dr. Balogh Ágota (PhD.)

Gál Ferenc Főiskola (Magyarország)

Dr. Lipcsei Imre (PhD.)

Gál Ferenc Főiskola (Magyarország)

Vida Júlia, Fest Sarolta (2019). A fóiskolai hallgatók életmódja és sporttal kapcsolatos szokásaik. Különleges Bánásmód, 5. (2). 19-27. DOI 10.18458/KB.2019.2.19

\begin{abstract}
Absztrakt
A szerzők kérdőívek segítségével tanulmányozzák, hogy a Szent István Egyetem Alkalmazott Bölcsészeti és Pedagógiai Karának főiskolai hallgatói ( $\mathrm{n}=127)$ mennyi időt töltenek a testhigiénia, az alvás, az étkezés, a tanulás, a szabadidő aktív és passzív kiaknázásával. Eredmények: Étkezés - a diákok nagy mennyiségben csokoládét, chipset fogyasztanak, míg a gyümölcs- és zöldségfogyasztásuk ezzel ellentétes. Mozgás - a rendszeres testnevelésen részt vevő hallgatók aránya nem több mint 21\%,55\% nem vesz részt sporttevékenységben, 13\% -uk nem végez testmozgást. Egyebek - a hallgatók 39\%-a naponta több mint 1-2 órát töltött számítógép vagy TV-készülék előtt. Az eredmények azt sugallják, hogy a tanárjelöltek értékrendjében az egészség helye túlságosan elmarad.
\end{abstract}

Kulcsszavak: életmód, egészségtudatosság, sport

Diszciplína: Egészségtudomány

\section{Abstract \\ COLLEGE STUDENT’S LIFE STYLE AND THEIR ATTITUDE TO SPORTS}

The authors studies by using questionnaires the amount of time spent by college students at the Applied Humanities and Pedagogy Faculty of Szent István University ( $\mathrm{n}=127)$ on body hygiene, sleeping, meal, participation in lessons, active-passive exploitation of free time. Results: Meal - the students consume in great amount chocolates, chips while their fruit and vegetable consummation seem backward. Move - proportion of students doing regular physical education is no more than $21 \%, 55 \%$ are not involved in any sporting activities, $13 \%$ do not like any body movement. Others $-39 \%$ of the students spent more than 1-2 hours daily in front of a computer or TV set. The results suggest that in the teacher candidates' scale of values the place of health falls too much behind.

Keywords: lifestyle, health consciousness, sport

Discipline: Health Science 
Napjainkban Magyarországon nincs igazán értéke a helyes életviteli szokásoknak, ezen belül a rendszeres testedzésnek. Ennek következményeként, bátran mondhatjuk, hogy nincs értéke az egészségnek sem, s mindez együtt jár a mozgásszegény életmóddal. A tapasztalat azt mutatja, hogy a főiskolákon is rendkívül sok az olyan hallgató, aki saját bevallása szerint nagyon keveset mozog, holott egyes kutatások (Gáldi, 2002) szerint az iskolai végzettség növekedésével együtt nő a fizikai aktivitást végzők gyakorisági aránya. Ennek az ellentmondásnak a feloldása érdekében végeztük el jelen vizsgálatunkat, mivel úgy véljük, hogy az életmód megváltoztatásában jelentős szerepe van a pedagógusnak. Jogosnak tűnik, hogy megkérdezzük: a pedagógusjelöltek hogyan vélekednek az egészségről, milyen szerepet szánnak a testmozgásnak a saját életükben.

\section{Az életmódról általában}

Az életmód a szükségletek kielégitése érdekében végzett tevékenységek rendszere, tehát konkrétabban az, hogy a társadalom tagjai mindennapi életükben milyen tevékenységeket végeznek, hol végzik ezeket, kik vesznek részt ezekben, miért végzik ezeket, mit jelentenek számukra ezek (Andorka, 2006). Az életmódnak, mint jelenségnek nincs egységes elnevezése gyakran azonos értelemben használják az életstílus, az életvitel és az életminőség fogalmát is.

Az ember legfőbb élettevékenységei a munka, az alvás, a játék, a szabadidő aktív eltöltése, a tanulás, a társas együttlét, a fogyasztás stb. Az, hogy az egyén hogyan osztja el az élettevékenységeit egy napon belül, többek között az idôtől függ. Az idó szubjektív megélését befolyásoló hatások - az idő múlásának módja és a benne elvégzett cselekvéseink, tevékenységeink értékelése - személyfüggő. Attól függ elsősorban, hogy milyen tulajdonságokkal, képességekkel rendelkezünk, valamint attól, hogy hogyan értékeljük tulajdonságainkat és tevékenységeinket. Korunk emberének alapvető időélménye az idő felgyorsulása, mely mindennapjaink valamennyi területére hatással van (Mező, 2017).

Az egyén aktivitását az emberi természet törvényei határozzák meg, mivel az ébrenlét és az alvás, illetve éber állapotban az aktivációs szint is ciklikusan változó periódusokra tagolódik. Az alvás a tudat fiziológiai beszúkülése, normális nyugalmi állapot, amelynek során a szervrendszerek visszanyerik múködésképességüket. Az ébrenlét és az alvás napi ciklusokban ismétlődik, ez a legfontosabb biológiai ritmus. A fáradtsági és aktivitási szint görbéje pedig a napszakok, hetek, hónapok, évszakok és életperiódusok függvényében is változik. Ezt a biológiailag egyedi adottságoktól és külső tényezőktől is meghatározott, ritmikusan váltakozó aktivitási szintet nevezik bioritmusnak.

\section{A sport életmódformáló funkciója}

A szükségletek kielégítése tevékenységek segítségével történik (ha éhesek vagyunk, élelmet keresünk, ha kulturálódni akarunk, színházba megyünk vagy olvasunk). „A sport az ember életében az alapvető szükségletek kielégítésére szolgáló alkalmas eszköz" (Bíróné, 2004). Ennek azonban - mint minden tevékenységnek - „értékmagasnak" kell lennie az egyén számára, hogy a szükségletek kielégítését, mint tevékenységet, tudatosan válassza a sokféle lehetőség közül. Igaz ugyan, hogy a jelen feltételek nem minden esetben biztosítanak megfelelő alapot a sport iránti szükséglet kielégítéséhez - például: uszodák, pályák, csarnokok, termek száma - mégis úgy gondoljuk, hogy komolyabb akadályokkal kell megküzdeni akkor, ha a szükségletek hiányoznak a sporttevékenység választásához. Egyes vizsgálatok (Biróné és mtsai, 2011) azt mutatják, hogy a sporttevékenység nem kielégítő módon épült bele az emberek életmódjába. Ugyanez elmondható a testkultúra egyes elemeiről is. Felmérések (Perényi és Petridis, 2015) igazolják, hogy a sport helye és jelentősége az egyéni, emberi viszonylatban nem ilyen egyértelmú.

Ez a hatás érvényesül a főiskolai hallgatók esetében is: a magyar főiskolai hallgatók több mint $40 \%$-a szabadidejében aktív mozgást nem végez, egyedüli mozgáslehetősége a heti 1-2 kötelezô testnevelési óra (Sebőkné, 1999). Ez a szám az életkor előrehaladtával jelentősen csökken. Az egyetemek, fő́iskolák utolsó évfolyamain az ülóéletmód jellemző, melynek egyenes következménye a testösszetétel és a kardio-respiratorikus tel- 
jesítmények változása (Frenkl és Mészáros, 1979). Holott a rendszeres fizikai aktivitásnak rendkívül sok kedvező élettani és pszichológiai hatása van például előnyös hatással van a mozgásszervi, valamint a szív - érrendszeri betegségek gyógyítására, emellett csökkenti az elhízást, az egészségre ártalmas szokásokat, s javítja az általános közérzetet. (Apor, 2005)

Az életmódbeli minták gyermekkorban alakulnak ki, amikor az egészséghez való hozzáállás még kedvező. Az iskolai testnevelésnek, melynek fó nevelő hatású eszközei a személyi és a tárgyi környezet, a természeti erők, az életmód, illetve a táplálkozás (Prisztóka, 1998) - meghatározó hatása van a későbbi felnőttkori fizikai aktivitás minőségére. (Bognár és mtsai, 2005). Nem lehet elégszer hangoztatni, hogy a felsőoktatás az utolsó nevelési szintér, ahol a testnevelés és sport műveltségi területének tanítási-tanulási folyamatán keresztül az egészséges életmód iránti értékítéletének és beállítódások tudatosítására, a tökéletes közérzet, a testi-lelki harmónia igényének a kialakítására még lehetôségünk van (Frenkl és Szabó, 1995).

\section{Kutatási cél}

A vizsgálat célja, információk gyújtése a hallgatói életmód tartalmáról, formájáról, melyek értékesek lehetnek az oktatás tervezéséhez is.
A hallgatók életritmusa, életstílusa sajátos jellegzetességekkel bír, amelyek eltérnek a társadalom nagyobb részében elfogadott normáitól. Empirikus vizsgálatunk során arra törekedtünk, hogy a hallgatói életmód órákban mérhetô kvantitatív leírása mellett az időfelhasználás magyarázó tényezőinek rendszerét feltárjuk. Munkánkban arról kívánunk számot adni, hogy a felsőoktatási intézmények hallgatói, közelebbről: a Szent István Egyetem Alkalmazott Bölcsészeti és Pedagógiai Karának főiskolai hallgatói hogyan rendezik hierarchikus rendbe a tevékenységek struktúráját.

A tevékenységrendszerük tekintetében vizsgáljuk a munkaidőt, a munkához kapcsolódó időt, a szabadidôt és a fiziológiai szükségletekre fordított időtartamot.

\section{Anyag és módszer}

Viæsgálati helyszín. Vizsgálatunkat a Szent István Egyetem Alkalmazott Bölcsészeti és Pedagógiai Karán végeztük.

Viæsgálati személyek Ezen intézmény 18 és 25 év közötti nappali tagozatos hallgatóit $(\mathrm{n}=127)$ kérdeztük életmódbeli és sportolási szokásaikról. A megkérdezettek 55\%-a a 18-20 éves korosztályból került ki. S mindössze a megkérdezettek 7\%, azaz 9 fô tartozott a 23-25 éves korosztályba (1.ábra).

\section{1. ábra. Életkor szerinti megoszlás. Forrás: Sžržók.}

9 fô, $7 \%$

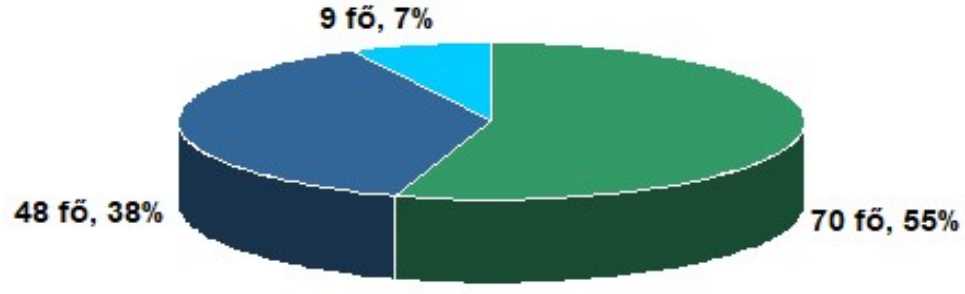


Vizsgálati módszer

140 kérdőív kiosztására került sor a kar különböző évfolyamos hallgatók között. Ebből 127 kérdőív érkezett vissza.

\section{Eredmények}

Vizsgálataink során a következő eredményeket kaptuk.

Az élettani szüleségletekre vonatkozó kérdéskörböl: $\mathrm{Al}$ vásra szánt idő tekintetében: a hallgatók nagy többsége napi 6-8 órát alszik, ami életkornak megfelelő. Ugyanakkor 43 \%-uk naponta dohányzik, ami kedvezőtlen adat. Vajon hogyan hat a dohányzás azoknak a szervezetére, akik „egészségük érdekében” végeznek aktív fizikai tevékenységet nap, mint nap? A válasz: abszolút károsan. Éppen a mozgás szempontjából egyik legfontosabb szervet- a tüdőt - támadja a dohányzás. Másik megdöbbentő adat a rendszere sen sportolók körében, hogy 65\%-a alkalmanként iszik alkoholtartalmú készítményeket. Az alkohol amellett, hogy károsítja a májat, az agyat és az idegeket, még hizlal is: valódi tápértéke nincs, az általa bevitt kalóriák az izomzat növelése helyett a zsírpárnák kialakulását eredményezik.
A felmérésből egyértelmúen kiderül, hogy a hallgatók zöménél a pedagógus pályára készülés nem vagy csak nagyon kis mértékben befolyásolja az életvitelt. Jelenleg értelmiségi életvitelre, átadásra alkalmatlan életmódminta jellemző a hallgatókra.

A következő kérdés a tisztálkodásra vonatkozott (2. ábra). A megkérdezett hallgatók többsége (56\%a) naponta legalább egy órát tölt tisztálkodással. Ez az időmennyiség elegendő napi szinten a hallgatók higiéniai ellátására. Azt is meg kell említenünk, hogy viszonylag nagy százalékuk (31\%) mindössze napi fél órát szán ezen tevékenységekre.

Egészséges táplálkozásra vonatkozó kérdésünk: Hányszor étkezik naponta? Itt külön kérdeztük rá a hideg és meleg ételek fogyasztására. Napi 1-szer mindössze 4-en étkeznek, ők minden esetben meleg ételt fogyasztanak. Ez nem felel meg az egészséges táplálkozás feltételeinek. Napi 2-szer étkezôk között már változatosabb képet mutatott az eredmény. Külön vettük azokat, akik reggelit és ebédet fogyasztanak, akik reggelit és vacsorát, illetve akik ebédet és vacsorát fogyasztanak (1. táblázat). Az egészségesebbnek tekinthetô a reggeli és ebéd fogyasztás, bár a napi 2-szeri étkezésétkezés nem elegendő.

2. ábra. Tisztálkodásra szánt idö megoszlása. Forrás: Sžerző́k.

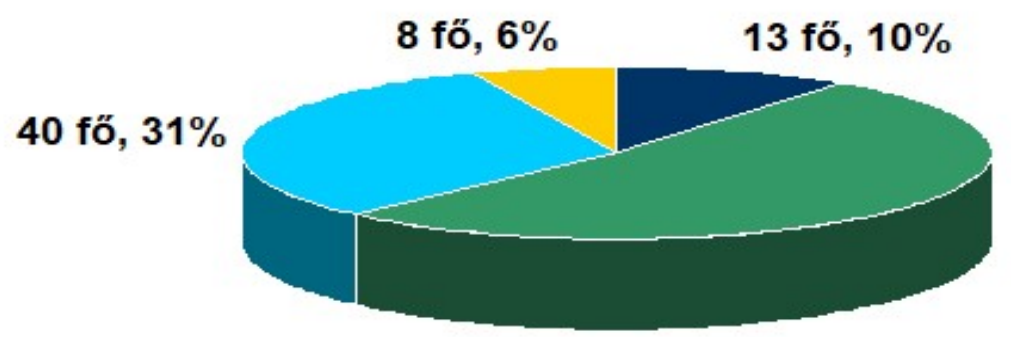

66 fö, $53 \%$

$\square>0,5$ óra $\quad 1$ óra $\quad 1,5$ óra $\quad 1,5$ óra $<$


1.táblázat. Az étkezés rendszeressége. Forrás: Szerzö́k.

\begin{tabular}{|c|c|}
\hline Napi 2-szer étkezők (n= 62) & Napi 3-szor étkezők (n= 61) \\
\hline $\begin{array}{l}\text { reggeli-ebéd: } 16 \text { fó, ebből... } \\
\text { - meleg ételt fogyasztó: } 5 \text { fó, } \\
\text { - hideg ételt fogyasztó: } 11 \text { fó } \\
\text { reggeli-vacsora: } 6 \text { fó, ebből... } \\
\text { - meleg ételt fogyasztó: } 6 \text { fó, } \\
\text { - hideg ételt fogyasztó: } 0 \text { fó } \\
\text { ebéd-vacsora: } 40 \text { fó, ebből... } \\
\text { - ebédre hideg ételt fogyasztó: } 23 \text { fó } \\
\text { - ebédre meleg ételt fogyasztó: } 17 \text { fó } \\
\text { - vacsorára hideg ételt fogyasztó: } 26 \text { fó } \\
\text { - vacsorára meleg ételt fogyasztó: } 8 \text { fó, }\end{array}$ & $\begin{array}{l}\text { reggeli } \\
\text { ebédnél } \\
\text { - hideg ételt eszik: } 16 \text { fó } \\
\text { - meleg ételt eszik: } 38 \text { fó } \\
\text { - aki meleget és hideget is fogyaszt: } 7 \text { fő } \\
\text { vacsorára } \\
\text { - hideg ételt eszik: } 38 \text { fő } \\
\text { - meleg ételt eszik: } 14 \text { fó } \\
\text { - meleg és hideg ételt egyaránt fogyaszt: } 9 \text { fó. }\end{array}$ \\
\hline
\end{tabular}

A nap első és egyben legfontosabb étkezése a reggeli. Ébredés után a legalacsonyabb a vércukorszint, ezért nagyon fontos, az első étkezés. A hallgatók nem mindegyike reggelizik. A reggeli a két tanóra között, szünetben szokott megtörténni tíz óra magasságában, de gyakran előfordul az is, hogy étkezést hagynak ki és ezáltal az első étkezésük az ebéd. Nincs ideje a hallgatóknak reggelit készíteni, mivel megpróbálják az alvásidôt kinyújtani. A reggeli étkezést gyakran egy kávé, egy szál cigaretta biztosítja.

A főiskola a hallgatói számára ebédszünetet nem biztosít, ennek okai leginkább a tanórák mennyiségében keresendők. Így a legtöbb hallgató számára az ebéd elfogyasztása sem kap nagyobb hangsúlyt, mint a reggeli. A hallgatóknak lehetőségük van a menzán étkezni, ugyanakkor a fiatalok gyakran időhiány miatt az otthonról hozott ételeket kény- telenek, akár hidegen is elfogyasztani. Abban az esetben, ha valaki mégis a menzát veszi igénybe, több étterem változatos menüi közül választhat. A szervírozott ételek lehetôséget adnak az egészséges ebéd elfogyasztására és az áraik is kedvezők. A külső környezet tanulmányozása alapján megállapítható, hogy a lehetőség megvan az egészséges táplálkozásra, csak a hallgatók nem élnek vele vagy azért, mert nincs elég idejük rá, vagy azért, mert nem fordítanak kelló figyelmet az étkezés minőségére.

Az egészséges táplálkozás témakörén belül kíváncsiak voltunk az étkezési szokásokra is. Erre irányuló kérdésünk: A fóétkezések között az alábbiak közül melyiket fogyasztod? (3. ábra).

3.ábra. Étkezési szokáasok. Forrás: Szerzơok.

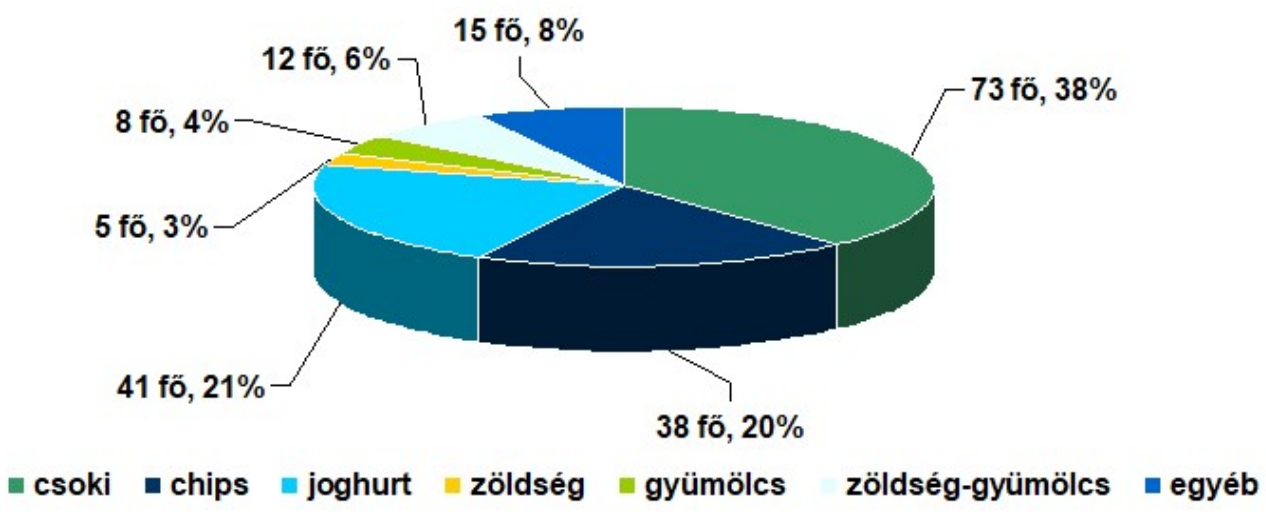


Az eredmények alapján megállapítható, hogy a megkérdezettek többsége nem étkezik egészségesen, mivel sokan (38 \%) csokit, míg 20\%uk chipset fogyaszt. Alacsony zöldséget és gyümölcsöt fogyasztók aránya. Gyümölcsöt a megkérdezettek mindössze 4\%-a fogyaszt, zöldséget 3\%-uk. Egyéb ételeket is felsoroltak, itt szerepelt puding, puffasztott rizs, keksz, ezt 8\%ban jelölték. Mindemellett meg kell említenünk, hogy az egészséges táplálkozás nem olcsó. Sok hallgató nem engedheti meg magának a rendszeres zöldség és gyümölcs fogyasztást az anyagi vonzat miatt.

Tanórákra való felkészülés témakörben a következőre voltunk kíváncsiak: Mennyi időt vesz igénybe a tanórákra való felkészülés? (4.ábra).
A válaszadásokból kitűnik, hogy a hallgatók között nagyon kevesen vannak, akik napi 1-2 óránál több időt fordítanak a felkészülésre (mindössze 16\%). Átlagosan napi 1-2 órát szánnak a felkészülésre, amennyit az órarendben foglalt tárgyak szükségessé tesznek. Természetesen azt is figyelembe kell venni, hogy ez a felmérés szorgalmi időszakban készült, bizonyosan más eredményeket kaptunk volna, ha vizsgaidőszakban kérdezzük erről a hallgatókat.

Az eredmények tükrözik, hogy a hallgatók viszonylag kevés időt töltenek a tanórán kívüli tanulással Lehetséges okok: 1) a kredit rendszer, mely lehetôvé teszi a nem teljesített tantárgyak újra felvételét, 2) a hallgatók hozzáállása, 3) a sok vizsgajavítási lehetőséget, 4) előfodulhat, hogy a tanulók megfelelő tanulási stratégiákat alkalmaznak.

4.ábra. Tanórákra való felkészüilés. Forrás. Szerző́k.

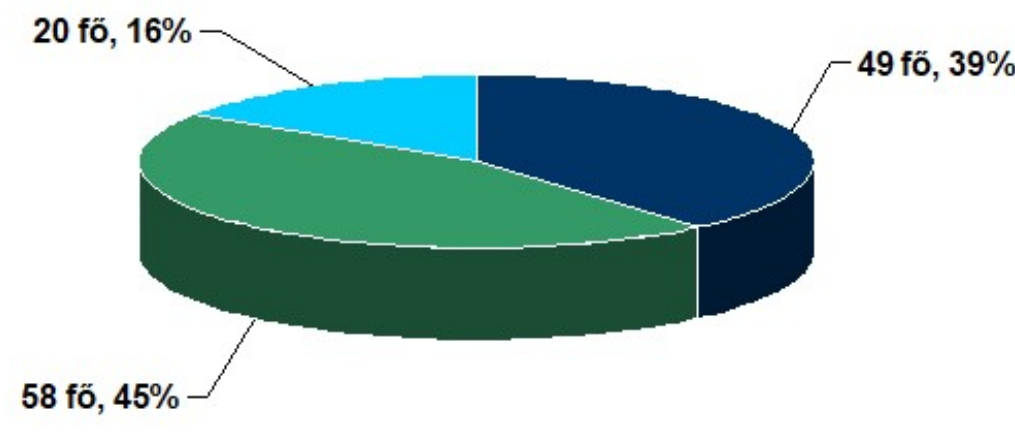

- <napi 1-2 óra

napi 1-2 óra

>napi 1-2 óra

Jelenlegi vizsgálatunkban megkülönböztettük a szabadidő aktív kihasználását és a szabadidő passzív eltöltését. Az aktív pihenésre vonatkozó kérdés a sportolásra vonatkozott (5. ábra), a passzívpihenés esetében a TV nézési és számítógépezési szokásokra kérdeztünk rá (7. ábra).

A hallgatók több mint fele csak akkor sportol, ha kedve van, pedig tudjuk, hogy az egészséges életmód fontos feltétele a sport. A Pedagógiai Karon kötelező testnevelés órák vannak.
Megállapítható, hogy ez igen hasznos, hiszen a megkérdezettek $11 \%$-a azt a választ adta, hogy csak akkor sportol, amikor kötelező. Aggodalomra ad okot, hogy a megkérdezettek mindössze 21\%-a sportol rendszeresen. Azok a hallgatók, akik nem végeznek rendszeres fizikai aktivitást szabadidejükben, egyrészt szabadidőhiányt és motivációs tényezőket, másrészt környezetből eredő objektív akadályokat említenek indokként, kifogásként. 
A Kar különböző sporttevékenységekre nyújt lehetőséget: röplabda, aerobik, kosárlabda, floor ball, asztali tenisz, teremfoci, zenés torna.

Kíváncsiak voltunk még arra is, hogy a rendszeresen sportolók közül ki milyen sportot úz (6. ábra). Sokan kerékpároznak, ami annak is betudható, hogy sokan bejárósok, így a lakóhelyüktől a buszmegállóig, vasútállomásig kerékpárral tudnak kijutni. Az egyik legfontosabb és legegészségesebb sportot, az úszást kevesen úzik, a megkér-

\section{5. ábra. Sportolás gyakorisága. Forrás: Szerzók}

dezetteknek mindössze 6\%-a. Ezzel kapcsolatban arra a következtetésre jutottunk, hogy az úszás pénzhez kötött, ́́gy sokan nem biztos, hogy megengedhetik maguknak, másik indok, hogy nem minden település rendelkezik uszodával. Egyéb sportok közül említették még a görkorcsolyázást, testépítést, zumba és jóga órákat. A hallgatók a labdajátékokat nem részesítették előnyben a többi sportággal szemben.

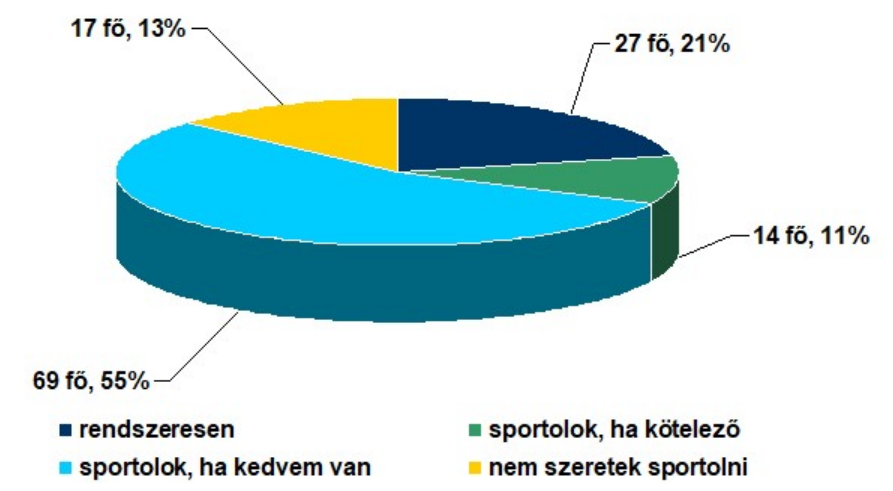

6. ábra. Sportolási típusok. Forrás: Sžerzőók.

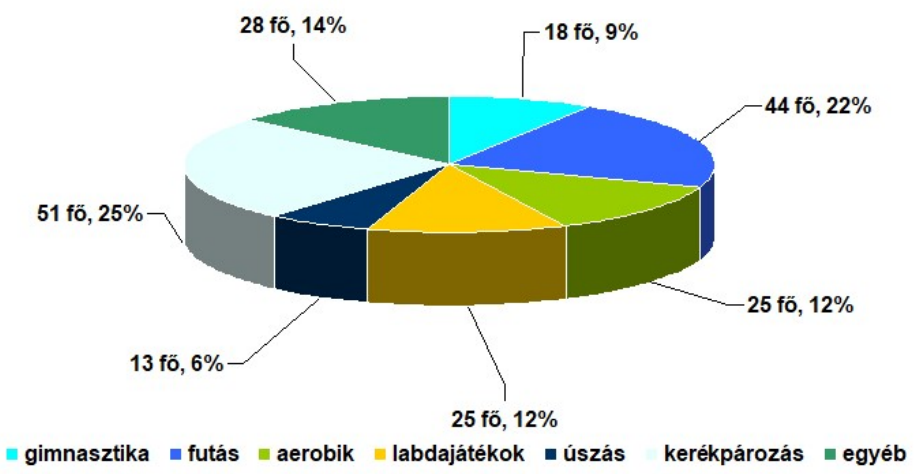


7. ábra. Passzív pihenéssel töltöttt idó. Forrás. Szerzơok.

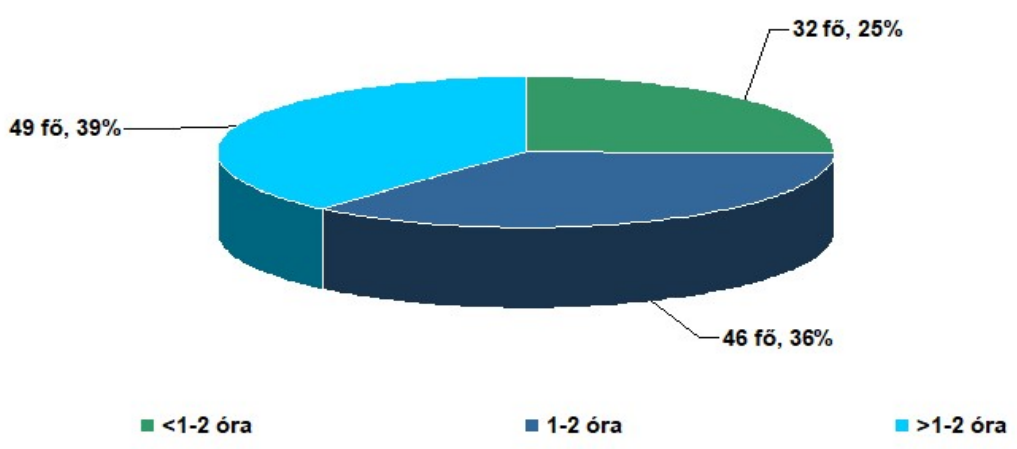

A passzív pihenésre vonatkozó idő más fơtevékenység - csoportokhoz képest meglehetősen magas időtartamban jelentkezett. A passzív pihenésre vonatkozó kérdésünk így hangzott: Mennyi időt töltesz naponta számítógép, tv előtt?

Érdekes eredményeket kaptunk ennél a kérdésnél, hiszen láthattuk, hogy a tanórákra való felkészülésre a hallgatók mindössze napi egy két órát szánnak, a számítógép, illetve tv előtt a megkérdezettek 39 \%-a több, mint 2 órát tölt. Ez valamelyest megmagyarázza azt a tényt is, hogy nagyon keveset mozognak, az ülő életmód válik jellemzôvé az utolsó évfolyamokon. A mozgásszegény életmód számos betegség kialakulását eredményezi. Mindezek alapján láthatóan nagy szükség van további vizsgálatokra, hogy a hallgatók fizikai aktivitás és inaktivitás kérdéseinek hátterét és problémarendszerét tisztázzuk.

\section{Zárógondolatok}

Az eredmények arról tanúskodnak, hogy a pedagógusképzésben résztvevő hallgatók nem foglalkoznak eleget a saját magukra vonatkozó egészséges életmód kialakításával. Felmerül a kérdés, képes lesz e a tanítójelölt az egészségnek, mint értéknek a közvetítésére? Kap-e annyi információt, ismeretet a tanulmányai során, ami elegendő ahhoz, hogy az általános iskolában az egészséges életmódra nevelést hitelesen közvetítse? Sajnos nem. A főiskolán elvégzett vizsgálatunk eredményei mind azt mutatják, hogy a leendő pedagógus még saját egészégének tényezőivel sincs tisztában, úgy tűnik változtatni szükséges a pedagógusképzés rendszerében, annak érdekében, hogy a tudatos egészségnevelés magas szintű értékké váljon a hallgatók értékrendjében.

\section{Irodalom}

Andorka, R. (2006). Bevezetés a szociológiába. Budapest: Osiris Kiadó.

Apor, P. (2005). Rehabilitációs ambuláns programok belgyógyászati betegeknek. Magyar Sporttudományi Szemle 3.

Bíróné Nagy E, Bognár J., Farkas J., Gombocz J., Hamar P., Kovács A., Mészáros János, Ozsváth Károly, Rétsági Erzsébet, Rigler Endre, Salvara, I. Marina, Szabó B., Tihanyiné Hős Á., Vináné Kokovay Á. (2011). Sportpedagógia - Kézikönyv a testnevelés és sport pedagógiai kérdéseinek tanulmányozásához: Dialóg Campus KiadóNordex Kft., Eger.

Bíróné, N. E. (2004). Sportpedagógia. BudapestPécs: Dialóg Campus Kiadó.

Bognár, J., Malina I., S. (2005). Testnevelő tanárok pályaválasztása, presztízse és pályaelhagyása, Magyar Sporttudományi Szemle 3.

Frenkl, R., Mészáros J. (1979). Physique and cardio-respiratory performance during medical university and physical education study (in Hungarian). Egésæségtudomány, 23:1-7.

Frenkl, R., Szabó, T. (1995). Psychological and medical aspects in the development of university sports-preliminary findings of a national survey. HungarianReview of Sports Medicine. 4:229238. 
Gáldi, G. (2002). Fizikai aktivitás Magyarországon az ezredfordulón. Magyar Sporttudományi Szemle, 3-4.16.

Mezô, K. (2017). A kreativitás idóbeli aspektusai. Doktori disszertáció. Debrecen.

Perényi, Sz., Petridis L. (2015). Bevezetés a sporttudományokba. Campus Kiadó, Debrecen.

Prisztóka, Gy. (1988). Testneveléselmélet, BudapestPécs: Dialóg Campus Kiadó.
Sebőkné, L. M. (1999). A szakmódszertan szerepe és társadalmi változásai a testnevelés oktatásában és tanítóképzésben. In Kovátsné Németh Mária (szerk.). Nyugat-Magyarországi Egyetem Apáczai Csere János Tanitókép̃ó Fóiskolai Kar Évkönyve. 119-126. 